\title{
Concentrations and dimensions of coated and uncoated asbestos fibres in the human lung
}

\author{
A MORGAN AND A HOLMES \\ From the Environmental and Medical Sciences Division, Atomic Energy Research Establishment, \\ Harwell, Oxfordshire OX11 ORA, UK
}

\begin{abstract}
Concentrations and length distributions of uncoated and coated amphibole-type fibres in samples of human lung taken at necropsy were measured by optical microscopy using the membrane filter technique that enables fibres with diameters down to about $0 \cdot 2 \mu \mathrm{m}$ to be detected. The subjects included 10 who died with mesothelial tumours, three with lung cancer, and eight of other causes. Measurements of fibre concentrations are compared with those of other workers. It can be deduced from the length distributions that fibres less than $5 \mu \mathrm{m}$ long are cleared from the lung more efficiently than longer ones. The clearance of short fibres appears to be inhibited in subjects with asbestosis, however. The length distributions of uncoated and coated fibres were dissimilar. In general, few fibres $<10 \mu \mathrm{m}$ in length were coated and few $>40 \mu \mathrm{m}$ in length were uncoated. The probability of a fibre of given length, however, becoming coated varied considerably from subject to subject. Possible reasons for this are discussed.
\end{abstract}

The inhalation of fibrous materials may cause lung fibrosis or tumours, which can be either bronchial or mesothelial in origin. Most studies with experimental animals have indicated that fibrogenicity is dependent on fibre length. ${ }^{1-3}$ Fibres are probably only actively fibrogenic if they exceed a critical length, which is probably about $10-20 \mu \mathrm{m}$. Studies on the carcinogenic effects of fibres have also emphasised the significance of length. ${ }^{4-7}$ Long fibres are thought to be more carcinogenic than short and long thin fibres may be particularly active in this respect.

Most current studies of asbestos fibres in human lung are concerned either with estimating the concentration of uncoated fibres present ${ }^{8}$ and their topographic distribution ${ }^{9}$ or with the identification of the fibre types. ${ }^{10}$ As many fibres in human lung are too thin to be detected with the optical microscope, transmission or scanning electron microscopes, often with analytical attachments, are generally used for such investigations. With the electron microscope, however, it is difficult to measure the length of long uncoated and coated fibres (which may exceed $300 \mu \mathrm{m}$ in length) and therefore to obtain accurate fibre length distributions.

There is a consensus among workers measuring asbestos fibre concentrations in air (using membrane

Received 26 March 1979

Accepted 22 May 1979 filters and phase contrast optical microscopy) that fibres with diameters equal to or greater than about $0.2 \mu \mathrm{m}$ can be detected. Pooley 11 has reported mean values for the diameters of various types of fibre isolated from human lung tissue. The values for crocidolite and amosite were 0.14 and $0.24 \mu \mathrm{m}$ respectively, which suggest that it should be possible to detect a reasonable fraction of amphibole fibres with the optical microscope. The corresponding value for chrysotile was $0 \cdot 11 \mu \mathrm{m}$. Ashcroft and Heppleston, ${ }^{12}$ who counted fibres in a FuchsRosenthal counting chamber, claimed to have detected between $12 \%$ and $30 \%$ of the total fibres present in human lung. It would be expected that this could be improved on using the membrane filter technique. A preliminary comparison of fibre densities on membrane filters by electron and optical microscopy indicates that it is possible to detect about $30 \%$ of crocidolite fibres and at least $50 \%$ of other amphiboles by optical microscopy.

In digesting lung tissue for the determination of either fibre concentration or dimensions, any process that may damage fibres either by shortening or by longitudinal splitting must be avoided. Ashcroft and Heppleston ${ }^{12}$ pointed out that drying tissue before maceration leads to fracture of the longer uncoated and coated fibres and that fibre counts may be exaggerated as a result. The rapid dimensional changes in and local overheating of 
Table 1 Details of subjects from whom lung tissue was obtained at necropsy

\begin{tabular}{|c|c|c|c|c|c|}
\hline $\operatorname{Ref}$ & $\operatorname{Sex}$ & $\begin{array}{l}\text { Age at } \\
\text { death }\end{array}$ & Cause of death & $\begin{array}{l}\text { Asbestosis }(A) \\
\text { or plaques }(P)\end{array}$ & Occupational exposure \\
\hline M1 & $\mathbf{F}$ & 60 & Mesothelioma & $\mathbf{P}$ & Gas mask factory $1940-5$ and $1955-9$ \\
\hline M2 & $\mathbf{M}$ & 56 & Mesothelioma & $\mathbf{A}$ & Cleaner in shipyard \\
\hline M3 & $\mathbf{M}$ & 70 & Mesothelioma & $\mathbf{P}$ & Asbestos factory most of working life \\
\hline M4 & $\mathbf{M}$ & 47 & Mesothelioma & $\mathbf{P}$ & General labourer at glass factory before 1965 \\
\hline M5 & $\mathbf{M}$ & 81 & Mesothelioma & $\mathbf{P}$ & Boiler maker 1913-62 \\
\hline M6 & $\mathbf{F}$ & 72 & $\begin{array}{l}\text { Spontaneous pleural } \\
\text { mesothelioma }\end{array}$ & - & Tobacco factory all her life \\
\hline M7 & $\mathbf{M}$ & 80 & Mesothelioma & $\mathbf{P}$ & Shipyard worker from 1922 to retirement in 1962 \\
\hline M8 & $\mathbf{M}$ & 64 & Mesothelioma & NA & Shipyard worker (driller) 1927-77 \\
\hline M9 & $\mathbf{M}$ & 75 & Mesothelioma & - & $\begin{array}{l}\text { Shipyard apprentice at 17. Joined LNER at 21. From } 1945 \text { to } \\
1967 \text { worked for BR engineering }\end{array}$ \\
\hline M10 & $\mathbf{M}$ & 76 & Mesothelioma & - & Chemical industry from 1931 until retirement in 1964 \\
\hline $\mathrm{Cl}$ & $\mathbf{M}$ & 56 & Lung cancer & NA & Pipe lagger for eight years before death \\
\hline $\mathrm{C} 2$ & $\mathbf{M}$ & 60 & $\begin{array}{l}\text { Undifierentiated lung } \\
\text { cancer }\end{array}$ & $\mathbf{P}$ & Worked in shipyard for unspecified period \\
\hline C3 & $\mathbf{M}$ & 70 & Adenocarcinoma of lung & NA & $\begin{array}{l}\text { Probably coalworker but worked in asbestos factory for one } \\
\text { year in } 1946\end{array}$ \\
\hline 01 & $\mathbf{M}$ & 56 & Diffuse reticulosarcoma & 二 & Docker \\
\hline $\mathrm{O} 2$ & $\mathbf{M}$ & 71 & Cirrhosis of the liver & $\mathbf{P}$ & Mixed paint containing asbestos up to 1958 . No exposure since \\
\hline O3 & $\mathbf{M}$ & 88 & Cardiac failure & - & Retired bricklayer \\
\hline O4 & $\mathbf{F}$ & 87 & Haemopericardium & - & NA \\
\hline O5 & $\mathbf{M}$ & 72 & Myocardial fibrosis & - & NA \\
\hline O6 & $\mathbf{F}$ & 77 & Pulmonary embolism & 一 & NA \\
\hline O7 & $\mathbf{M}$ & 19 & Multiple injuries & 一 & NA \\
\hline O8 & $\mathbf{F}$ & 60 & Cerebral haemorrhage & 一 & Housewife \\
\hline
\end{tabular}

NA $=$ Information not available.

tissue during low-temperature ashing make this procedure even more suspect than oven drying. It is well-known that sonication can result in the longitudinal splitting of both amphibole and chrysotile fibres, and must also be avoided. Despite contraindications, drying, low-temperature ashing, and sonication are included in several published procedures for isolating fibres from lung.

In the present investigation the concentrations of amphibole-type fibres were measured in 21 samples of human lung taken at necropsy. The concentrations of uncoated and coated fibres were measured separately; no attempt was made to include chrysotile fibres, most of which would not have been detected. The length of each fibre (both uncoated and coated) was measured and the length distributions determined in each sample for which sufficient data were available.

\section{Methods}

MATERIAL

The samples of lung tissue examined were obtained from 10 patients who died with mesothelial tumours, three with other types of lung cancer, and eight who died of other causes. In some cases samples of associated tumour and pleural plaques were also analysed. The mesothelioma lung specimens had been submitted to the Manchester Pneumoconiosis Medical Panel by coroners in the north west of
England in 1977 and 1978. Table 1 gives details of the subjects, together with available information on their occupational histories.

\section{DIGESTION OF LUNG TISSUE}

A technique for the digestion of either fresh or formalin-fixed lung tissue using hydrogen peroxide has been described by Morgan et al..$^{13}$ More recent work has shown that the hypochlorite technique ${ }^{9}$ is more convenient. A block (about $0.5 \mathrm{~g}$ ) is cut from the tissue with a clean scalpel and weighed. A second, adjacent, sample about $1 \mathrm{~g}$ in weight is taken to determine the fresh/dry weight ratio. The sample to be analysed is placed in a $50 \mathrm{~cm}^{3}$ plastic screw-top centrifuge tube (Falcon, Cockeysville, USA) and $15 \mathrm{~cm}^{3}$ of Parozone bleach (Jeyes, Thetford, Norfolk) added. The tube is left overnight at room temperature. If digestion is incomplete, a further $5 \mathrm{~cm}^{3}$ of bleach may be added and the tube heated at $50^{\circ} \mathrm{C}$. When digestion is complete the tube is cooled and diethyl ether $\left(10 \mathrm{~cm}^{3}\right)$ added. The capped tube is shaken to extract lipids, centrifuged, and the ether removed with a Pasteur pipette. The extraction is repeated with a further $10 \mathrm{~cm}^{3}$ of ether, and residual solvent is removed by heating the tube on a water bath. A few drops of ethanol are added and the walls cleaned with a rubber "policeman" to ensure that all fibres are in suspension. The volume is made up to $25 \mathrm{~cm}^{3}$ with water and an aliquot (generally $2.5 \mathrm{~cm}^{3}$ ) filtered on a $2.5 \mathrm{~cm}$ diam 
Millipore GS membrane filter (pore size $0.22 \mu \mathrm{m}$ ). The filter is washed well with distilled water and allowed to dry. Half of the filter is placed on a microscope slide and cleared either with acetone vapour or with a dimethylformamide/acetic acid/ water mixture (Le Guen, personal communication). Finally, the cleared filter is mounted in neutral mounting medium (Gurr) under a coverslip. All reagents used in the digestion procedure should be filtered through membrane filters before use. Even diethyl ether was found to contain fibres. Appropriate blank samples are prepared from time to time to confirm the absence of fibres.

For transmission electron microscopy studies the remainder of the Millipore filter is sputtered with a carbon film. A small disc ( $3 \mathrm{~mm}$ diam) is cut from the filter and placed on an electron microscope grid. The filter is dissolved with acetone vapour, thus depositing the fibres and carbon film on to the grid.

The advantage of this digestion technique is that all operations are carried out in the same tube. Although the sample is centrifuged during the extraction of lipids, only the upper (organic) phase is removed so that losses of fibre, which have been reported by Ashcroft and Heppleston to occur during centrifuging, ${ }^{12}$ are avoided. Details and an assessment of the procedure will be published elsewhere.

\section{MEASUREMENT OF FIBRES}

Uncoated fibres greater than about $2.5 \mu \mathrm{m}$ long were counted and sized under phase contrast with a Zeiss photomicroscope III using a magnification of about $\times 640(\times 10$ eyepiece, $\times 1.6$ Optovar, $\times 40$ objective) and Porton-type eyepiece graticule. Coated fibres were counted and sized at a magnification of about $\times 256(\times 16$ objective). To measure the density of uncoated fibres continuous scans parallel to the cut edge of the filter were made, until either 200 fibres had been measured or an area of about $2 \mathrm{~mm}^{2}$ had been covered. To measure the density of coated fibres it was sometimes necessary to scan the entire half filter. Applying the appropriate corrections, the results were expressed as $10^{6}$ fibres/g dry weight of tissue for uncoated fibres and $10^{3}$ fibres/g dry weight for coated fibres. In terms of wet weight, values were 5 to 10 times lower. The length of each coated or uncoated fibre was measured and classified in the categories given in tables 4 and 5 .

\section{Results}

Table 2 gives the concentrations of uncoated and coated fibres in lung tissue. The values for uncoated fibres ranged from less than $0 \cdot 1$ to $370 \times 10^{6} / \mathrm{g}$ dry weight. The corresponding values for coated fibres were 0 to $11500 \times 10^{3} / \mathrm{g}$ dry weight. Included in table 2 are values for the uncoated/coated fibre ratio in cases where the result can be derived with reasonable accuracy. The presence of non-fibrous material, indicative of occupational exposure is also noted. Particles of coal were present in most samples examined. The particles of calcium carbonate in $\mathrm{C1}$ (fig 3) are probably an artifact arising from the use of calcium acetate to neutralise the formalin injected into the lung.

Table 2 Concentrations of uncoated and coated fibres in lung tissue

\begin{tabular}{|c|c|c|c|c|c|}
\hline $\operatorname{Ref}$ & $\begin{array}{l}\text { No of } \\
\text { determinations }\end{array}$ & $\begin{array}{l}\text { Uncoated } \\
\left(10^{\circ} / g \text { dry wt }\right)\end{array}$ & $\begin{array}{l}\text { Coated } \\
\left(10^{2} / g d r y w t\right)\end{array}$ & $\begin{array}{l}\text { Uncoated/ } \\
\text { Coated }\end{array}$ & $\begin{array}{l}\text { Non-fibrous } \\
\text { material }\end{array}$ \\
\hline $\begin{array}{l}\text { M1 } \\
\text { M2 } \\
\text { M3 } \\
\text { M4 } \\
\text { M5 } \\
\text { M6 } \\
\text { M7 } \\
\text { M8 } \\
\text { M9 } \\
\text { M10 }\end{array}$ & $\begin{array}{l}2 \\
2 \\
1 \\
3 \\
4 \\
2 \\
1 \\
1 \\
3 \\
2\end{array}$ & $\begin{array}{c}13 \\
370 \\
1.3 \\
3.6 \\
42 \\
0.6 \\
0.5 \\
1.0 \\
0.6 \\
<0.1\end{array}$ & $\begin{array}{c}340 \\
11500 \\
5 \\
86 \\
4840 \\
3 \cdot 4 \\
880 \\
140 \\
35 \\
8\end{array}$ & $\begin{array}{c}38 \\
31 \\
270 \\
42 \\
9 \\
200 \\
0 \cdot 6 \\
7 \\
17 \\
10\end{array}$ & $\begin{array}{l}\overline{+} \\
+ \\
++ \\
++ \\
- \\
++ \\
+ \\
+ \\
+\end{array}$ \\
\hline $\begin{array}{l}\text { C1 } \\
\text { C2 } \\
\text { C3 }\end{array}$ & $\begin{array}{l}3 \\
6 \\
2\end{array}$ & $\begin{array}{r}0.4 \\
0.1 \\
<0.1\end{array}$ & $\begin{array}{r}100 \\
3 \cdot 3 \\
1 \cdot 0\end{array}$ & $\begin{array}{r}4 \\
40 \\
-\end{array}$ & $\begin{array}{l}+++a \\
+ \\
+++b\end{array}$ \\
\hline $\begin{array}{l}\text { O1 } \\
\text { O2 } \\
\text { O3 } \\
\text { O4 } \\
\text { O5 } \\
\text { O6 } \\
\text { O7 } \\
\text { O8 }\end{array}$ & $\begin{array}{l}4 \\
3 \\
3 \\
2 \\
3 \\
3 \\
3 \\
3\end{array}$ & $\begin{array}{r}0.9 \\
2.1 \\
<0.1 \\
<0.1 \\
<0.1 \\
<0.1 \\
<0.1 \\
<0.1\end{array}$ & 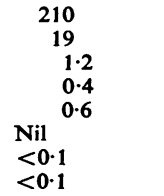 & $\begin{array}{r}5 \\
110 \\
17 \\
- \\
- \\
- \\
-\end{array}$ & $\begin{array}{l}++ \\
+ \\
++b \\
+ \\
+ \\
- \\
-\end{array}$ \\
\hline
\end{tabular}

$\mathbf{a}=$ Calcium carbonate.

$\mathrm{b}=$ Coal. 
Table 3 Concentrations of uncoated fibres in samples of mesothelial tumour or plaque

\begin{tabular}{lllc}
\hline Ref & $\begin{array}{l}\text { No of } \\
\text { determinations }\end{array}$ & $\begin{array}{l}\text { Tumour }(T) \\
\text { or plaque }(P)\end{array}$ & $\begin{array}{l}\text { Fibres } \\
\left(10^{\circ} / g \text { dry wt }\right)\end{array}$ \\
\hline M5 & 1 & T & 0.03 \\
M7 & 1 & T & 0.03 \\
M8 & 1 & T & $<0.01$ \\
M9 & 1 & T & $<0.01$ \\
M10 & 1 & T & 0.01 \\
O1 & 1 & P & $<0.01$ \\
\hline
\end{tabular}

Short uncoated fibres were detected in samples of tumour and in plaques and table 3 gives their concentrations. No coated fibres were detected in any of the samples of tumour or plaque examined.

Table 4 gives measurements of the length distributions of uncoated fibres. The results are expressed as the frequency of fibres in six length categories from $<4.9 \mu \mathrm{m}$ to $>80 \mu \mathrm{m}$. The median lengths obtained from cumulative distributions plotted on a logarithmic probability paper (fig 1) are included in table 4. In some cases insufficient fibres were detected to permit analysis of the data in this way. Table 5 gives corresponding values for coated fibres.

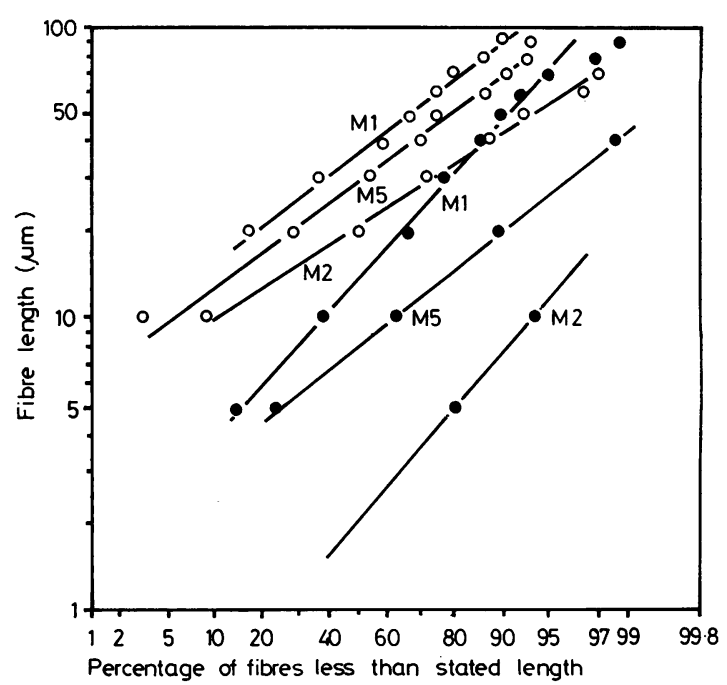

Fig 1 Length distributions of coated (o) and uncoated (๑) fibres from subjects $M 1, M 2$, and $M 5$.

Table 4 Length distributions of uncoated fibres

\begin{tabular}{|c|c|c|c|c|c|c|c|c|}
\hline \multirow[t]{2}{*}{ Ref } & \multirow{2}{*}{$\begin{array}{l}\text { No of } \\
\text { fibres }\end{array}$} & \multicolumn{6}{|c|}{$\%$ of fibres of length $(\mu m)$} & \multirow{2}{*}{$\begin{array}{l}\text { Median } \\
\text { length }(\mu \mathrm{m})\end{array}$} \\
\hline & & $2 \cdot 5-4 \cdot 9$ & $5-9.9$ & $10-19 \cdot 9$ & $20-39 \cdot 9$ & $40-79 \cdot 9$ & $>80$ & \\
\hline M1 & 120 & $15 \cdot 0$ & $23 \cdot 3$ & $28 \cdot 3$ & $19 \cdot 2$ & $12 \cdot 4$ & $1 \cdot 8$ & 14 \\
\hline M2 & 217 & $72 \cdot 4$ & $19 \cdot 8$ & $7 \cdot 8$ & - & - & 一 & 2 \\
\hline M3 & 106 & $36 \cdot 8$ & $50 \cdot 0$ & $8 \cdot 5$ & $4 \cdot 7$ & 一 & - & 6 \\
\hline M4 & 231 & $7 \cdot 4$ & $24 \cdot 2$ & $26 \cdot 5$ & $27 \cdot 7$ & $12 \cdot 6$ & 1.6 & 15 \\
\hline M5 & 538 & $24 \cdot 9$ & $38 \cdot 3$ & $26 \cdot 4$ & $9 \cdot 1$ & $1 \cdot 3$ & - & 8 \\
\hline M7 & 27 & $11 \cdot 1$ & 55.6 & $33 \cdot 3$ & - & - & - & 9 \\
\hline M8 & 44 & $20 \cdot 5$ & 40.9 & 25.0 & $13 \cdot 7$ & - & - & 8 \\
\hline M9 & 66 & $15 \cdot 2$ & $33 \cdot 0$ & $37 \cdot 9$ & $9 \cdot 1$ & $4 \cdot 5$ & - & 10 \\
\hline $\mathrm{Cl}$ & 121 & $11 \cdot 6$ & $24 \cdot 8$ & $32 \cdot 2$ & 26.4 & 4.9 & - & 13 \\
\hline $\mathrm{C} 2$ & 88 & $22 \cdot 7$ & 38.6 & 23.9 & $12 \cdot 5$ & $2 \cdot 2$ & - & 9 \\
\hline 01 & 45 & 20.0 & $42 \cdot 2$ & $17 \cdot 8$ & $17 \cdot 8$ & $2 \cdot 2$ & - & 9 \\
\hline $\mathrm{O} 2$ & 90 & $25 \cdot 6$ & $37 \cdot 8$ & 25.6 & $10 \cdot 0$ & $1 \cdot 1$ & - & 8 \\
\hline
\end{tabular}

Table 5 Length distributions of coated fibres

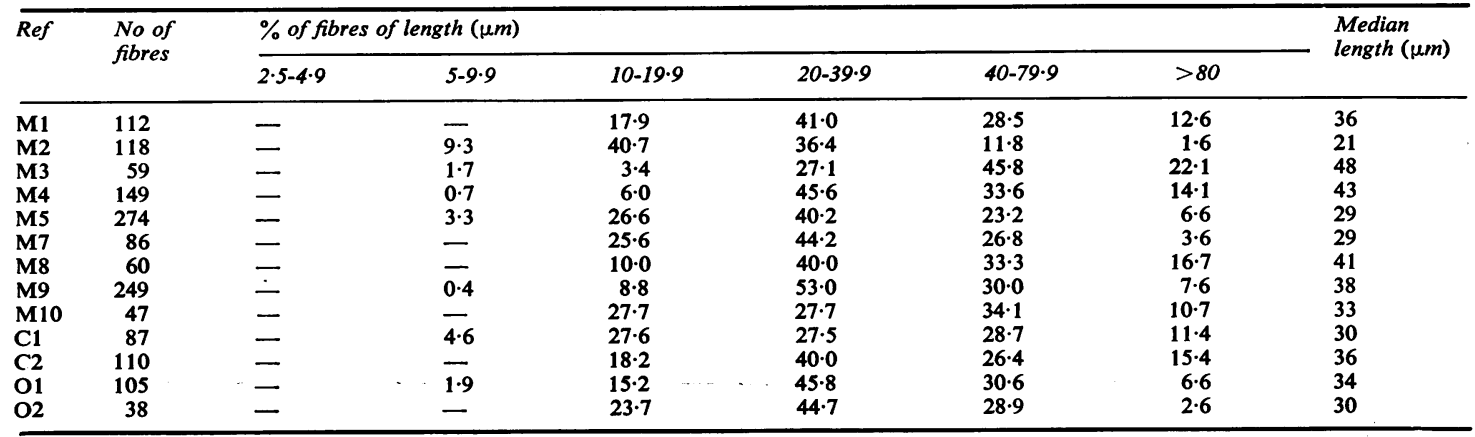




\section{Discussion}

Uncoated fibres were detected in all the samples of lung tissue examined. The concentrations of uncoated fibres in those members of the non-neoplastic " $O$ " series who were unlikely to have been exposed to asbestos occupationally were relatively low ( $<0.1 \times 10^{6} / \mathrm{g}$ dry weight of lung). M10 and C3 also fell within the same range. For subjects likely to have been exposed to asbestos occupationally the values ranged from $0 \cdot 1$ to $370 \times 10^{6} / \mathrm{g}$ dry weight. The only exception to this general rule was M6. Although this subject worked in a tobacco factory all her working life, the concentration of uncoated fibres in her lungs was above the lower limit of the occupationally exposed range.

The best series with which to compare these results is that of Whitwell et al ${ }^{14}$ who measured the concentration of fibres (uncoated plus coated) in the lungs of patients who had died with mesothelial tumours, lung cancer, and of other causes. These workers used the counting chamber technique and included only those fibres exceeding $6 \mu \mathrm{m}$ in length as against $2.5 \mu \mathrm{m}$ in the present study. The effect of this higher cut-off would be to underestimate fibre concentrations, particularly in a case such as M2, where a high proportion of fibres are $<5 \mu \mathrm{m}$ long, and also in non-occupationally exposed subjects in whose lungs short fibres predominate. In Whitwell's normal control series ${ }^{14}$ the fibre concentration was less than $0.1 \times 10^{6} / \mathrm{g}$ dry weight in all samples, and most were below $0.01 \times 10^{6}$. In his mesothelioma series $80 \%$ of the lungs had concentrations exceeding $0.1 \times 10^{6} / \mathrm{g}$ dry weight as against $90 \%$ in the present (smaller) series. In the series published by Ashcroft and Heppleston ${ }^{12}$ the concentration of uncoated fibres in subjects likely to have been exposed to asbestos occupationally, but without asbestosis, ranged from $0 \cdot 1$ to $16.4 \times 10^{6} / \mathrm{g}$ dry weight. In five subjects with moderate asbestosis the mean value was $203 \times 10^{6}$. The present results accord with the findings of the earlier studies.

Concentrations of uncoated fibres in the samples of tumour and plaque examined were, without exception, relatively low ( $<0 \cdot 1 \times 10^{6} / \mathrm{g}$ dry weight). The concentration of fibre in the tumour samples examined did not appear to be correlated with that in adjacent lung tissue. No coated fibres were detected in any of the samples of tumour or plaque examined.

The concentrations of coated fibres in people likely to have been exposed to fibres occupationally (not necessarily in the asbestos industry itself) ranged from 1 to $11500 \times 10^{3} / \mathrm{g}$ dry weight of lung. In lung samples from people without evidence of occupational exposure the upper limit appeared to be about $0.5 \times 10^{3} / \mathrm{g}$ dry weight, and in one subject no coated fibres were detected.

One of the main objectives of this study was to obtain evidence to support the contention that short $(<5 \mu \mathrm{m})$ uncoated fibres are cleared from the lung via the airways as has been shown by Morgan et al ${ }^{13}$ to occur in rats. Gibbs ${ }^{15}$ has reported that, of the

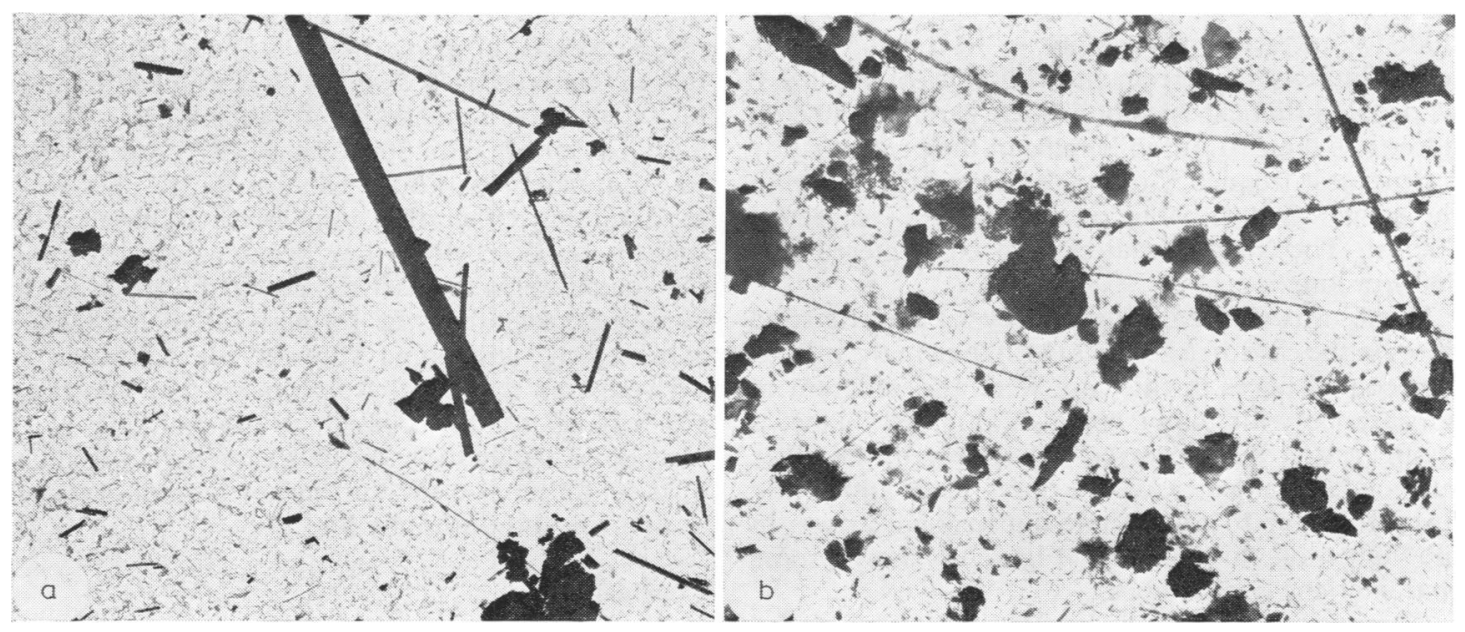

Fig 2 (a) Electron micrograph of fibres isolated from lungs of subject M2 showing predominance of short (< $5 \mu m$ ) fibres and wide variation in thickness. Thickest fibre about 1 um in diameter. (b) Electron micrograph of fibres isolated from lungs of subject M1 showing predominance of relatively long fibres. Thickest fibre about $0 \cdot 2 \mu \mathrm{m}$ in diameter $($ both $\times 2400)$. 
airborne fibres produced in various operations in the asbestos industry, generally over $90 \%$ are less than $5 \mu \mathrm{m}$ in length. The percentage of fibres of this length deposited in the alveolar region of the lung is likely to be at least as high due to the interception of long fibres in the small conducting airways. Table 4 gives length distributions of uncoated fibres for subjects in which more than 25 such fibres were measured. Omitting case M2, for reasons discussed below, the mean frequency of fibres less than $5 \mu \mathrm{m}$ long was only $19 \%$, which supports the contention that fibres in this range are removed preferentially from the lung, presumably by macrophage-mediated transport to the terminal bronchiole followed by mucociliary clearance. In $\mathrm{M} 2$, the only case of asbestosis, the value was $72 \%$ and fig $2 \mathrm{a}$ illustrates quite clearly the predominance of short fibres in this case. We suggest that the anomalous result from M2 is a direct consequence of the asbestosis and the inability of fibres of any length to be cleared from fibrotic areas of lung. Further work is required to substantiate this conclusion.

In general, the greatest frequency of fibres was found in the 5-10 $\mu \mathrm{m}$ range indicating that fibres in this category are cleared less efficiently than shorter ones. In some subjects no uncoated fibres longer than $40 \mu \mathrm{m}$ were detected but in others, notably M1 and M4, about $15 \%$ of the fibres fell into this category. Pooley ${ }^{11}$ reported an upper limit of $40 \mu \mathrm{m}$ for fibres of crocidolite and amosite in human lung but it is clear from the present work that longer uncoated fibres may be present in many cases.

The length distribution of coated fibres is quite different from that of uncoated. On average, less than $1 \%$ of coated fibres were $<10 \mu \mathrm{m}$ long. This lower limit is in agreement with that of Pooley, ${ }^{16}$ who stated that asbestos bodies are rarely formed on fibres less than $10 \mu \mathrm{m}$ in length. In the present study the greatest frequency of coated fibres was found in the range $20-40 \mu \mathrm{m}$ but on average $10 \%$ exceeded $80 \mu \mathrm{m}$. The longest coated fibre encountered was $360 \mu \mathrm{m}$ long.

There was a greater frequency of short-coated fibres in the case of asbestosis (M2) than in the others. The coated fibres in this case were also different in appearance with many being of dumbell shape, a configuration that occurred only rarely in the other subjects examined. Coated fibres had apparently fused together to form three-dimensional arrays in the lungs of this subject. Figure 3 shows some characteristic coated fibres.

Comparing the length distributions of uncoated and coated fibres shows that the longer the fibre the greater the probability of it becoming coated. The probability of a fibre becoming coated, however, varies considerably from subject to subject. By combining the length distributions of uncoated and coated fibres with their densities (fibres $\mathrm{mm}^{-2}$ ) on the filter it is possible to calculate, for each subject, the probability of a fibre of given length becoming coated. Taking the 20-40 $\mu \mathrm{m}$ range, for example, the probability of such fibres being coated was $100 \%$ in M2. Corresponding values for M1, M4, and M5 were $5 \%, 13 \%$, and $26 \%$ respectively. In view of the significance attached to the presence of long fibres in the lung it seems important to understand the reasons for the observed variation in body formation from subject to subject. It could be due either to variations in the response of individuals to long fibres or the differences in the type and relative quantities of fibres present. Examination of the uncoated fibres in M1 with the electron microscope showed that they were all relatively thin (see fig $2 b$ ), and many were only just resolved with the optical microscope. This subject worked in a gas mask factory and was almost certainly exposed only to crocidolite, which suggests that long fibres of intrinsically thin-fibred amphiboles, such as crocidolite, may be coated less readily than thick.

Values for the uncoated/coated ratio vary considerably. As the time between the cessation of exposure and death increases, the value for this ratio will fall due to the removal of short fibres from the lung. In one case (M7) who died at the age of 80 after 16 years in retirement, more coated than uncoated fibres were detected.

At the 1969 Conference on Pneumoconiosis in Johannesburg, Thomson described the asbestos body as the tombstone of the asbestos fibre, implying that it had no pathological significance. If it is accepted, however, that it is the long fibres that initiate pathological changes in the lung then the fact that, in some cases of mesothelioma, virtually all fibres longer than $20 \mu \mathrm{m}$ have been coated leads to an apparent paradox. This can be resolved only by assuming either that long fibres initiate pathological changes before they become coated or that the coated fibres themselves are capable of doing so. It is suggested that the former is the more likely explanation, and some support for this may be derived from the fact that it appears that thin fibres are not as readily coated as thick. This could provide an explanation for the greater carcinogenicity of crocidolite vis-a-vis the thicker amphiboles such as amosite and anthophyllite.

\section{Conclusion}

We suggest that the measurement of the total number of uncoated fibres in the lung is likely to provide a poor index of pathologically significant dose. This is because the number of very short 

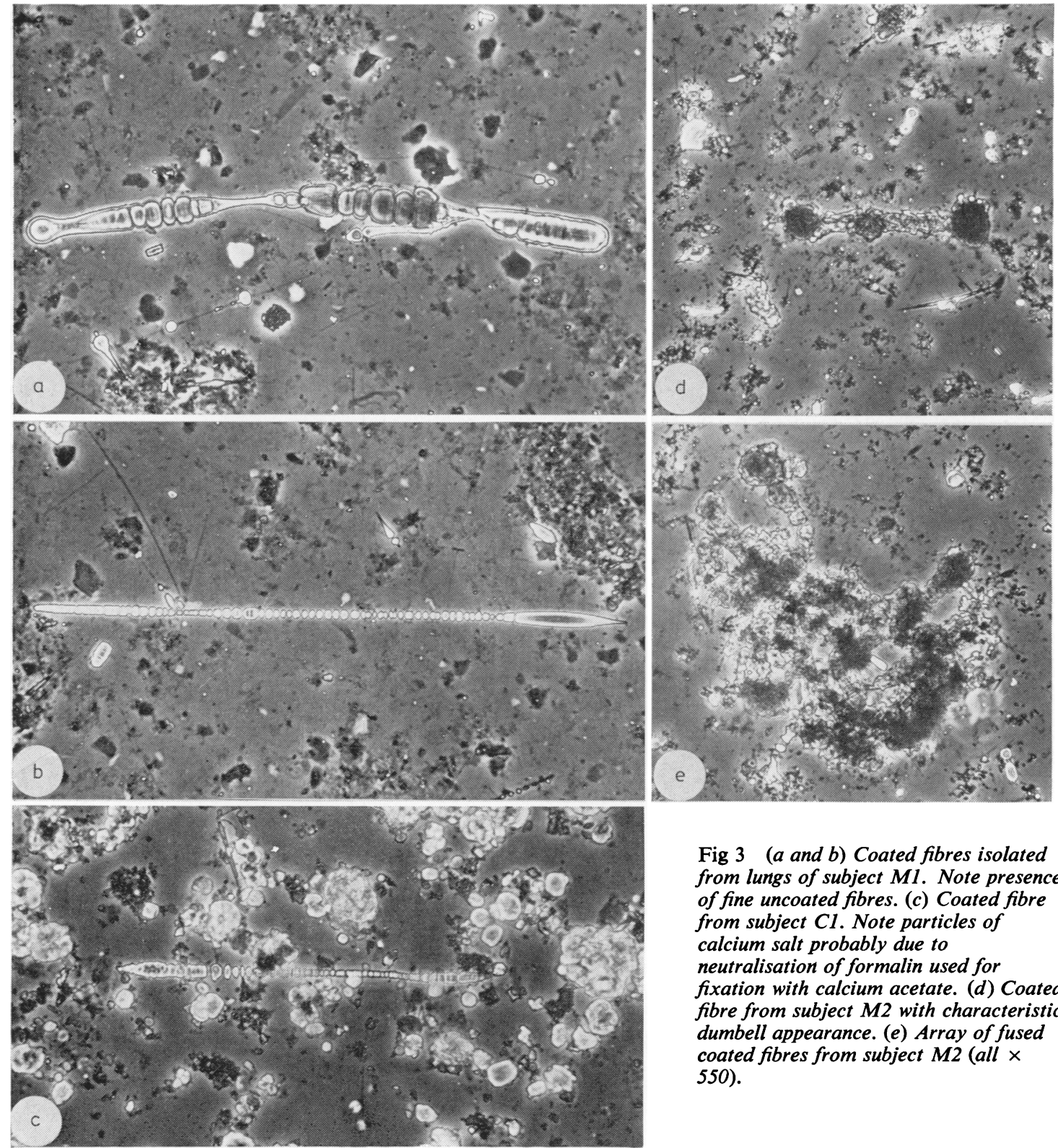

Fig 3 ( $a$ and $b$ ) Coated fibres isolated from lungs of subject M1. Note presence of fine uncoated fibres. (c) Coated fibre from subject $C 1$. Note particles of calcium salt probably due to neutralisation of formalin used for fixation with calcium acetate. (d) Coated fibre from subject $M 2$ with characteristic dumbell appearance. (e) Array of fused coated fibres from subject M2 (all $\times$ $550)$.

(and probably pathologically insignificant) fibres is highily variable depending as it does not only on the exposure itself but also on the time available for clearance and whether or not asbestosis is present. If, as suggested by Davis, ${ }^{17}$ only fibres greater than $20 \mu \mathrm{m}$ in length are of pathological significance, then only such fibres should be measured. Many fibres in this category will exist in coated form.

We gratefully acknowledge the support of the Asbestosis Research Council and of the EEC Environmental Research Programme (Project 277-77-10 ENV-UK). We also thank members of the Asbestosis Research Council for their constructive 
comments. We acknowledge the technical help of Mr R J Talbot and Mr J Pritchard, who obtained the electron micrographs. Samples of lung tissue were provided by Dr Whitwell, Broadgreen Hospital, Liverpool, and Dr Cowdell, Radcliffe Infirmary, Oxford.

\section{References}

' Vorwald AV, Durkan TM, Pratt PC. Experimental studies of asbestosis. AMA Arch Ind Hyg Occup Med 1951;3: 1-43.

2 Beck EG, Bruch J, Friedrichs KH, Hilscher W, Pott F. In: Walton WH, ed. Inhaled Particles III. Vol 1. Old Woking, Surrey: Unwin Bros, 1971:477-87.

${ }^{3}$ Wright GW, Kuschner M. The influence of varying lengths of glass and asbestos fibres on tissue response in guinea pigs. In: Walton WH, ed. Inhaled Particles IV. Vol 2. Oxford: Pergamon Press, 1977:455-74.

4 Maroudas N, O'Neal C, Stanton MF. Fibroblast anchorage in carcinogenesis by fibres. Lancet $1973 ; 1: 807-9$.

${ }^{5}$ Stanton MF, Layard M, Tegeris A, Miller E, May M, Kent E. Carcinogenicity of fibrous glass. Pleural response in the rat in relation to fibre dimension. $J$ Natl Cancer Inst 1977;58:587-603.

${ }^{6}$ Davis JMG, Beckett ST, Bolton RE, Collings P, Middleton AP. Mass and number of fibres in the pathogenesis of asbestos-related lung disease in rats. $B r J$ Cancer 1978;37:673-88.

${ }^{7}$ Friedrichs KH. Proceedings of SOEH Meeting on Occupational Exposures to Fibrous and Particulate Dust, Washington, 1977 (in press).
${ }^{8}$ Friedrichs $\mathrm{KH}$, Einbrodt $\mathrm{HJ}$. The measurement of fibre concentration in lung dusts. Zentralbl Bakteriol (Orig B) $1976 ; 161: 545-50$.

- Sebastien P, Fondimare A, Bignon J, Monchaux G, Desbordes J, Bonnaud G. Topographic distribution of asbestos fibres in human lung in relation to occupational and non-occupational exposure. In: Walton WH, ed. Inhaled Particles IV. Vol 2. Oxford: Pergamon Press, 1977:435-44.

10 Pooley FD. The use of an analytical electron microscope in the analysis of mineral dusts. Philos Trans $R$ Soc Lon (Series A) 1977;286:625-38.

11 Pooley FD. In: Glen HW, ed. Proceedings of Asbestos Symposium, Johannesburg 1977. Randburg, S Africa: National Institute for Metallurgy, 1978:31.

12 Ashcroft T, Heppleston AG. The optical and electron microscopic determination of pulmonary asbestos fibre concentration and its relation to the human pathological reaction. J Clin Pathol 1973;26:224-34.

13 Morgan A, Talbot RJ, Holmes A. Significance of fibre length in the clearance of asbestos fibres from the lung. $B r J$ Ind Med 1978;35:146-53.

14 Whitwell F, Scott J, Grimshaw M. Relationship between occupation and asbestos fibre content of the lungs of patients with pleural mesothelioma, lung cancer and other diseases. Thorax 1977;32:377-86.

15 Gibbs GW. In: Glen HW, ed. Proceedings of Asbestos Symposium, Johannesburg 1977. Randburg, S Africa: National Institute for Metallurgy, 1978:28-30.

${ }^{16}$ Pooley FD. Asbestos bodies, their formation, composition and character. Environ Res 1972;5:363-79.

17 Davis JMG. Proceedings of SOEH Meeting on Occupational Exposures to Fibrous and Particulate Dust, Washington, 1977 (in press). 